\title{
The improvements of the ships of opportunity program in MFS-TEP
}

\author{
G. M. R. Manzella ${ }^{1}$, F. Reseghetti ${ }^{1}$, G. Coppini ${ }^{2}$, M. Borghini ${ }^{3}$, A. Cruzado ${ }^{4}$, C. Galli ${ }^{3}$, I. Gertman ${ }^{5}$, T. Gervais ${ }^{6}$, \\ D. Hayes ${ }^{9}$, C. Millot $^{6}$, A. Murashkovsky ${ }^{5}$, E. Özsoy ${ }^{7}$, C. Tziavos $^{8}$, Z. Velasquez ${ }^{4}$, and G. Zodiatis ${ }^{9}$ \\ ${ }^{1}$ ENEA CLIM, Forte S.Teresa, Pozzuolo, 19036 Lerici, Italy \\ ${ }^{2}$ INGV, Via Donato Creti 12, 40128 Bologna, Italy \\ ${ }^{3}$ CNR ISMAR, Sezione di La Spezia, Pozzuolo, 19036 Lerici, Italy \\ ${ }^{4}$ CSIC CEAB, Access Cala St. Francesc, 14, 17300 Blanes, Spain \\ ${ }^{5}$ IOLR, POB 8030, Tel Shikmona Haifa 31080, Israel \\ ${ }^{6}$ CNRS LOB COM, POB 330, ZPB 83507 La Seyne-sur-mer, France \\ ${ }^{7}$ IMS METU, PK 28 Erdemli, Icel 33731, Turkey \\ ${ }^{8}$ HCMR, POB 712, 19013 Anavissos, Attiki, Greece \\ ${ }^{9}$ Oceanography Centre, University of Cyprus, Nicosia, Cyprus
}

Received: 9 May 2006 - Published in Ocean Sci. Discuss.: 18 October 2006

Revised: 30 January 2007 - Accepted: 9 May 2007 - Published: 23 May 2007

\begin{abstract}
The Ships Of Opportunity Program in the Mediterranean Sea was established at the end of 1999, in the framework of the Mediterranean Forecasting System - Pilot Project (MFS-PP). Many improvements have been made in data collection, transmission and management. Calibration of selected XBTs and a comparison of XBTs vs. CTDs during some research cruises have assured the quality of the data. Transmission now allows receiving data in full resolution by using GSM or satellite telecommunication services; management is offering access to high quality data and view services. The effects of technological and methodological improvements in the observing system are assessed in terms of capability to represent the most important circulation features. The improved methodologies have been tested during the Mediterranean Forecasting System - Toward Environmental Prediction (MFS-TEP) - Targeted Operational Period (MFS-TOP), lasting from September 2004 to February 2005. In spite of the short period of measurements, several important aspects of the Mediterranean Sea circulation have been verified, such as eddies and gyres in the various sub-basins, and dense water formation processes in some of them (vertical homogeneous profiles of about $13^{\circ} \mathrm{C}$ down to $\sim 800 \mathrm{~m}$ in the Provençal, and of about $14.9^{\circ} \mathrm{C}$ down to $\sim 300 \mathrm{~m}$ in the Levantine have allowed defining an index of dense water formation).
\end{abstract}

Correspondence to: G. M. R. Manzella
(manzella@ santateresa.enea.it)

\section{Introduction}

A Ships Of Opportunity Program (SOOP) was established in the Mediterranean in September 1999, on behalf of the EC funded project Mediterranean Forecasting System - Pilot Project (MFS-PP, Pinardi et al., 2003). Temperature-XBT profiles were collected along six transects crossing the western and the eastern basins from North to South and one transect crossing the whole sea from east to west. These transects were designed to specify, in each of the sub-basins ${ }^{1}$ (the Algero-Provençal, the Tyrrhenian, the south Adriatic, the Ionian and the Levantine), the variability of the main circulation features (Özsoy et al., 1991, 1993; POEM Group, 1992; Hecht and Gertman, 2001; Fusco et al., 2003; Zodiatis et al., 2005a; Millot and Taupier-Letage, 2005a).

The program provided data that were assimilated in the Modular Ocean Model (MOM), used in MFS-PP for forecasting the physical properties of the Mediterranean Sea (Pinardi et al., 2003; Demirov et al., 2003). The data allowed also updating the general circulation scheme of the sea (Manzella et al., 2001).

In MFS-PP, the technology was the same as that used in the international SOOP program (Smith et al., 2000): LM Sippican XBTs (T7 essentially, maximum depth $760 \mathrm{~m}$ ) for data acquisition and ARGOS for data transmission. The temperature profiles were sub-sampled by the ARGOS software and coded for transmission on the GTS (Global Telecommunications System) in the BATHY format (AODC, 1999; AODC

\footnotetext{
${ }^{1}$ Note the specific use of terms such as sea, basin and sub-basin, following Millot and Taupier-Letage (2005a).
}

Published by Copernicus Publications on behalf of the European Geosciences Union. 
2001; Cook and Sy, 2001). After the end of the pilot project, the raw - full resolution data were transmitted by using GSM or satellite telephones as modems. The quality control procedures was modified to include all the steps of the delayed mode data.

From September 1999 to June 2005 the Mediterranean SOOP has provided more than 9000 XBT profiles that have been assimilated in numerical models forecasting the Mediterranean Sea circulation. The database offers also the possibility to study seasonal and inter-annual variability. The program is now evolving into a full Volunteer Observing Ships (VOS) system providing sea-temperature profiles and meteorological data. For this reason it will be briefly named as MFS-VOS hereafter.

The project Mediterranean Forecasting System - Toward Environmental Prediction (MFS-TEP) has provided the opportunity to test the two main elements of MFS-VOS:

- the data collection strategy (including sampling design, technologies for data collection and for data transmission)

- the near-real time (NRT) data management (including NRT QC, and data access)

The main objective of the project was the development of an efficient data collection and management system for its transformation into an operational, more automated and multi-parametric VOS system.

In order to consolidate MFS-VOS the following issues were addressed in MFS-TEP:

- the data collection system in order to define the long term design

- the methodologies and strategies for the future operational system.

- the quality of services provided (i.e. quality of data and easy access)

The paper is presenting the procedures used in MFS-PP, materials and methods used in MFS-TEP and underline the major improvements done both in technology and procedures for data processing (Sect. 2), Sect. 3 describe the data collected in MFS-TEP and demonstrates the capability of the observing system to specify the main circulation features of the Mediterranean Sea. The services provided by MFS-VOS are presented in Sect. 4, and discussion and conclusions are in Sect. 5.

The data collection in MFS-TEP started in May 2004 along some transects and the observing system was fully operational during the so-called TOP from September 2004 to February 2005. The paper presents mainly the TOP data, although data collection is continuing along some transects.

\section{Materials and methods}

The main requirements of the SOOP were defined in MFSPP. An ideal sampling design is based on four goals:

- provide repetitive measurements along transects from coast to coast,

- the transects must cross significant dynamical features of the circulation,

- the sampling distance should resolve, as well as possible, the mesoscale,

- the technologies for data collection must be robust and simple, to be used on ships of opportunity, eventually by ship personnel.

The experience of MFS-PP indicated that there was a need for technology allowing full resolution data and metadata transmission in order to avoid wrong interpolations and misinterpretation of the ocean dynamics.

Other requirements were defined in MFS-TEP, in terms of services to be provided to the forecasting systems as well as to intermediate and end users:

- intermediate users need QC data for their particular goals, as they are producers of other services and the access to data should be based on mutual satisfaction;

- end users are interested in products (e.g. maps of data, changes with respect to climatology, etc.). The satisfaction of end users is of paramount importance to sustain the observing system.

Technologies for data acquisition and transmission and methodologies for quality assurance/control have been analysed and selected in order to assure a high quality of data. The quality of data is assured by international agreed protocols as well as some additional criteria. Quality assurance of field work includes best practices for data collection (practices that must be applied in all ships). Data must provide significant information on most important circulation features in the investigated area. Quality control of data, that is done in near-real time (i.e. within $24 \mathrm{~h}$ from the data collection) by applying all the delayed mode criteria.

It must be underlined that the MFS-VOS data collection was operated only in deep waters, i.e. probes were not dropped in sea areas shallower than $200 \mathrm{~m}$. The high variability in dynamics and physical properties of shelf/coastal is not detected by the MFS-VOS systems.

\section{Improvements of technologies and methodologies in MFS-VOS}

\subsection{MFS-VOS pilot phase}

In the pilot phase of MFS-VOS (1999-2000) data were collected by means of LM Sippican systems composed by hand 
Table 1. The MFS-PP message content transmitted by using ARGOS satellite system. SST is the absolute sea surface temperature. CRC is the checksum.

\begin{tabular}{lcccc}
\hline & Unit & precision & number of bits & Total number of bits \\
\hline XBT version & & & 1 & 1 \\
XBT type & & & 2 & 2 \\
Time & $\min$ & $2 \mathrm{~min}$ & 10 & 10 \\
SST & ${ }^{\circ} \mathrm{C}$ & 0.1 & 9 & 9 \\
Prof(i) & $\mathrm{m}$ & $1 \mathrm{~m}(0-560 \mathrm{~m})$ & 9 & 126 \\
& & $2 \mathrm{~m}(>560 \mathrm{~m})$ & & \\
$\Delta$ temp(i) & ${ }^{\circ} \mathrm{C}$ & 0.1 & 7 & 98 \\
CRC & & & 10 & 10 \\
Total number of bits & & & & 256 \\
\hline
\end{tabular}

launchers LM3 and MK12 processors. Temperature profiles were obtained by using T7 and T4 XBT probes providing data down to 760 and $460 \mathrm{~m}$ respectively.

The quality control procedures were the same adopted in the international Ship Of Opportunity Program (e.g. Cook and Sy, 2001) slightly modified to take into account the physical characteristics of the Mediterranean. An onboard quality control was performed in automated way by an ARGOS software on each profile in this manner:

- no test from 0 to $5 \mathrm{~m}$

- minimum temperature $2^{\circ} \mathrm{C}$

- maximum temperature $34^{\circ} \mathrm{C}$

- maximum temperature inversion (between 0-200m depth) $4.5^{\circ} \mathrm{C}$

- maximum temperature inversion (below $200 \mathrm{~m}$ ) $1.5^{\circ} \mathrm{C}$

- maximum temperature gradient $3^{\circ} \mathrm{C} / \mathrm{m}=$

The changes were operated essentially to specify (Manzella et al., 2003)

1. the characteristics of the relatively warm Levantine Intermediate Water (LIW),

2. the thickness of the water of Atlantic origin (AW) and

3. the vertical homogeneity associated with the dense water formation process.

The specific changes to the original ARGOS software are herewith described.

LIW temperature increase. Due to the artificial increase of temperature caused by the XBT wire stretching, the original software was containing an "end of profile check", which automatically was eliminating the part of the profile below $200 \mathrm{~m}$ having a temperature increase. In the oceans this can be due to strong currents. In the Mediterranean the increase of temperature below $200 \mathrm{~m}$ is due to the presence of the relatively warm LIW. The end of profile check was eliminated.

Vertical homogeneity. The original version was controlling the temperature difference between the upper and lower layers which must be greater than $2-10^{\circ} \mathrm{C}$. Also in this case the control was changed in order to provide data in vertically homogeneous areas.

Number of significant points. The old software was providing only those significant points necessary to define the vertical profile, which could be less than 15 . The new version was always calculating 15 significant points from surface down to $460 \mathrm{~m}$.

The revised ARGOS data transmission code was transmitting messages of 256 bits with the precision and number of bits shown in Table 1. The sea surface temperature was an absolute value, the others were differences with the previous value.

Although the important improvements in the ARGOS code, it was impossible to have full information on metadata (position, date, time, type of XBT) and data (depth and temperature values). The position was approximate and many important temperature features were not detected in an satisfactory way (Manzella et al., 2003).

In particular, the sub-sampled data could lead to losses, inter alia, of signals related to the core properties of most of the Mediterranean waters, corresponding to the strong thermocline during summer and to the relative increase of temperature associated with LIW.

All these reasons obliged us to changes technologies for data transmission, and, as a consequence, all the protocols and methodologies for quality assurance/control.

3.2 MFS-VOS improvements in data acquisition, transmission and quality control

Temperature profiles were obtained by using Deep Blue, T7 and T4 XBT probes, hand launcher, MK12 or MK21 card, a GPS and a PC. The LM Sippican software was set to extend the nominal depth for the data collection from $760 \mathrm{~m}$ to 
Table 2. The MFS-TEP-VOS sampling design. The number of XBT was defined to sample the mesoscale at 10 nautical mile resolution. Each transect was done every month from September 2004 to February 2005. Data were also collected before and after this period in the Genova-Palermo and Limassol-P. Said transects.

\begin{tabular}{lcccl}
\hline transect & $\begin{array}{c}\text { transect length } \\
(\mathrm{km})\end{array}$ & $\begin{array}{c}\text { number of XBTs } \\
\text { per cruise }\end{array}$ & $\begin{array}{c}\text { number of XBTs for } \\
\text { entire period }\end{array}$ & ship company \\
\hline Haifa-Messina & 1260 & 126 & 756 & ZIM \\
Barcelona-Arzew & 350 & 35 & 210 & C.S./Osprey \\
Sete-Tunis & 500 & 50 & 300 & Delom \\
Genova-Palermo & 400 & 40 & 240 & GNV \\
Pireus-Thessaloniki & 190 & 19 & 114 & Daedalous \\
Limassol-P.Said & 260 & 26 & 156 & Louis \\
Mersin-Alexandria-Ýstanbul & 500 & 50 & 300 & Turkon \\
& & & Total XBTs 2076 & \\
\hline
\end{tabular}

about $1000 \mathrm{~m}$ for Deep Blue and T7 and from 460 to $600 \mathrm{~m}$ for $\mathrm{T} 4$ so that it was possible to use more extensively the copper wire in the probes. Usually good temperature data were obtained down to about $900 \mathrm{~m}$ for Deep Blue and T7, and to about $550 \mathrm{~m}$ for $\mathrm{T} 4$.

Another small improvement was the use, in some cases, of "industrial computers" in order to have a better portability of the data collection system.

Data transmission was achieved using a normal GSM phone/modem for Internet connection. The edf - full resolution LM Sippican files were compressed and sent attached to an e-mail. This simple improvement was made possible by the GSM coverage available in the Mediterranean region.

After Spring 2005, satellite telecom system was tested. The Globalstar was selected since it was offering good transmission rate and coverage. This transmission is now used during 'cruises of opportunity' (COP) i.e. research vessels are provided with XBTs for the collection of temperature profiles during their activities.

Transmitting the full resolution profiles needed to change the quality control (QC) procedures. The software developed was based on Medar-Medatlas protocols (MedAtlas Group, 1994) and contained all the steps of the delayed mode quality control:

- gross range check,

- position control,

- elimination of spikes,

- re-sampling at 1-m interval,

- Gaussian smoothing,

- general malfunction control,

- comparison with climatology.

Two visual checks were added at the beginning and at the end of the QC procedure, in order to detect the end of a given profile and look at the overall consistency of the profiles (Manzella et al., 2003). Additional implementations in quality control procedures are described in the paper by Reseghetti et al. (2007).

The quality of data was assured by calibration of some XBTs extracted from different batches in La Spezia NURC (NATO Undersea Research Centre). Static calibration was done at 4 temperatures $\left(12.5,16.0,20.0\right.$ and $24.0^{\circ} \mathrm{C}$ ): all measured values were larger than actual ones with maximum differences ranging from $0.04^{\circ} \mathrm{C}$ (at $12.5^{\circ} \mathrm{C}$ ) to $0.08^{\circ} \mathrm{C}$ (at $24.0^{\circ} \mathrm{C}$ ). It is noteworthy that the calibration was adapted to the open Mediterranean characteristics, were temperature between $12-28^{\circ} \mathrm{C}$ are normally expected. The differences of $0.4-0.8^{\circ} \mathrm{C}$ between XBT measurement values and calibration bath is within the error expected for the LM Sippican probes $\left(0.1^{\circ} \mathrm{C}\right)$. A more analytical assessment of the errors associated to XBT measurements is carried out in the paper by Reseghetti et al. (2007).

\subsection{Sampling design and data collection}

The sampling design is part of the quality assurance protocols defined in MFS-VOS and here described in Sect. 2. Any sampling design of a SOOP is strongly dependent on ship availability and company travel schedules. But there is also another factor affecting the program that is the budget consistency, which dictates limitations and choices to the monitoring system.

The sampling strategy was designed on the experience of MFS-PP. The Table 2 is reporting the initial design, the number of XBTs for each transect, and the total of XBTs necessary for TOP, i.e. for a period demonstrating all the potential application of the MFS-VOS system.

In MFS-TEP the data collection started on May 2004, along two transects (Limassol-Port Said and GenovaPalermo). In September 2004 the MFS-TEP-VOS system was fully operational. Some changes were decided in order to improve the observing system and extend it in areas not 


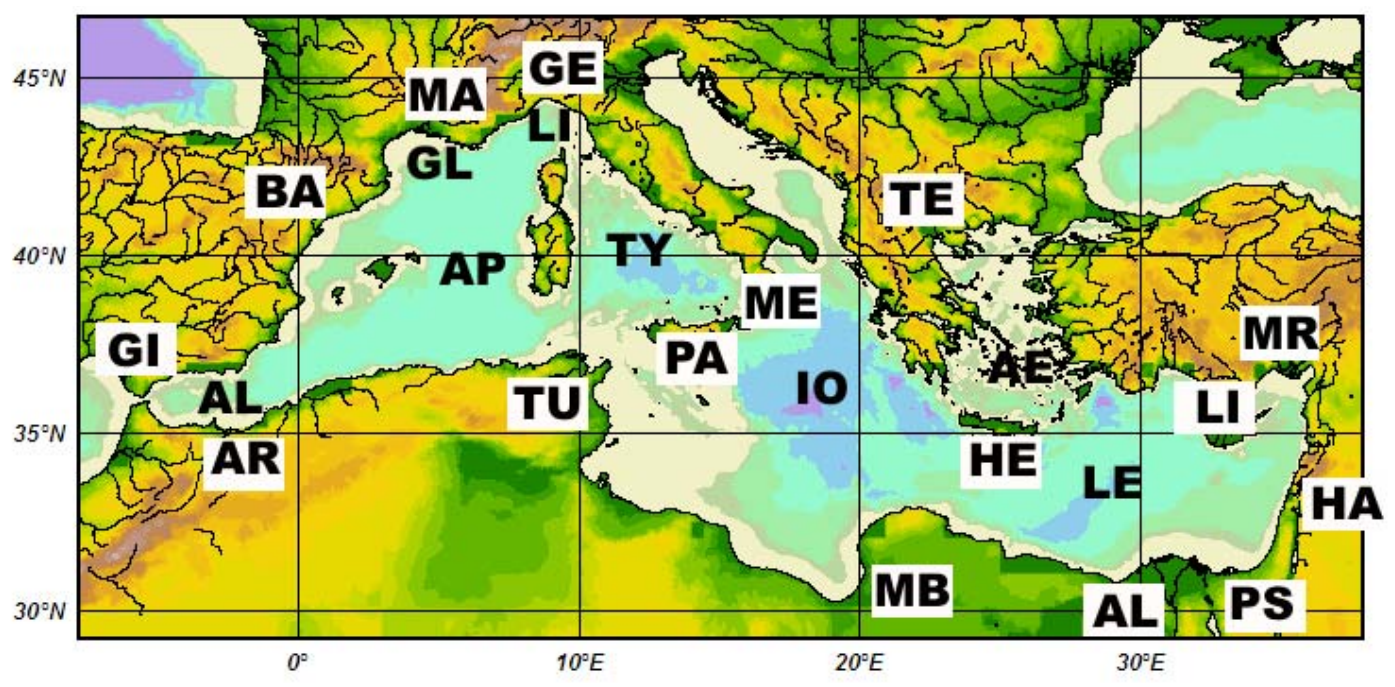

Fig. 1. The Mediterranean Sea. The letters in white boxes indicate the start-end ports of the MFS-VOS program. The other letters indicate the main basins of the Mediterranean Sea.

Ports: $\mathrm{AL}=$ Alexandria, $\mathrm{AR}=$ Arzew, $\mathrm{BA}=$ Barcelona, $\mathrm{GE}=$ Genova, GI $=$ Gibraltar, $\mathrm{HA}=\mathrm{Haifa}, \mathrm{HE}=\mathrm{Heraklion}, \mathrm{LI}=\mathrm{Limassol}, \mathrm{MA}=$ Marseille, $\mathrm{MB}=$ Mersa el Brega, $\mathrm{ME}=$ Messina, $\mathrm{MR}=$ Mersin, $\mathrm{PA}=$ Palermo, $\mathrm{PS}=$ Port Said, $\mathrm{TE}=\mathrm{Thessaloniki}$, TU $=$ Tunis

Seas: $\mathrm{AE}=$ Aegean Sea, AL = Alboran Sea, AP = Algero-Provencal basin, GL = Gulf of Lion, $\mathrm{IO}=$ Ionian Sea, $\mathrm{LE}=\mathrm{Levantine}$ basin, $\mathrm{LI}=$ Ligurian Sea, TY = Tyrrhenian Sea.

covered before. Of particular importance was the replacement of the Barcelona-Arzew transect by the BarcelonaMersa el Brega one. MFS-TEP-VOS system thus allowed collecting data in an area not sampled before for many decades.

The complete numbers of XBT data collected in the MFSVOS program from 1999 to June 2005 are shown in Fig. 2a, in particular the MFS-TEP- VOS data collected from May 2004 to June 2005 are presented in Fig. 2b. The MFS-TEP - VOS transects were repeated monthly, while the COP transects were occasional.

The data collection and control were then organised to deliver data with a relatively short time delay (possibly less than $24 \mathrm{~h}$ ) and in time for the weekly data assimilation process. Nevertheless, due to constraints such as ships availability, duration of transects and monthly data collection (Raicich and Rampazzo, 2003), the sampling was not optimal for a forecasting system.

\section{Capabilities of the observing system}

The analysis of the VOS data carried out at the end of MFSPP (Fusco et al., 2003) gave main results about the capability to provide data in real time for assimilation. Furthermore, the data allows defining intra- and inter-annual variability of thermal structures along transects.
Circulation features specified in MFS-PP were:

- instability of the circulation of AW having high temporal and spatial variability, but also long life times and deep extent (i.e. Millot, 1999);

- the location of LIW along-slope around Sardinia (Millot, 1987);

- cyclonic along-slope gyre in the whole northern part of the western basin (Millot, 1999);

- doming of isotherms in the central Tyrrhenian in front of the Bonifacio Straits, due to Ekman pumping (Marullo et al., 1995);

- doming of isotherms in the Ionian, indicating the restoration of the cyclonic circulation in 1998 (Manca, 2000; Fusco et al., 2003) after the Eastern Mediterranean Transient that lasted for the 90's (Malanotte Rizzoli et al., 1999; Klein et al., 1999; Klein et al., 2000);

- isotherm deepening associated to Pelops, Ierapetra and Cyprus and Shikmona anti-cyclonic eddies (Hecht and Gertman, 2001; Zodiatis et al., 2001; Zodiatis et al., 2005a);

- doming of isotherms south of Crete and off MersaMatruh.

The particular features detected in the MFS-TEP period are described below, selectively using data to illustrate these features. In the past, different schematic descriptions of 

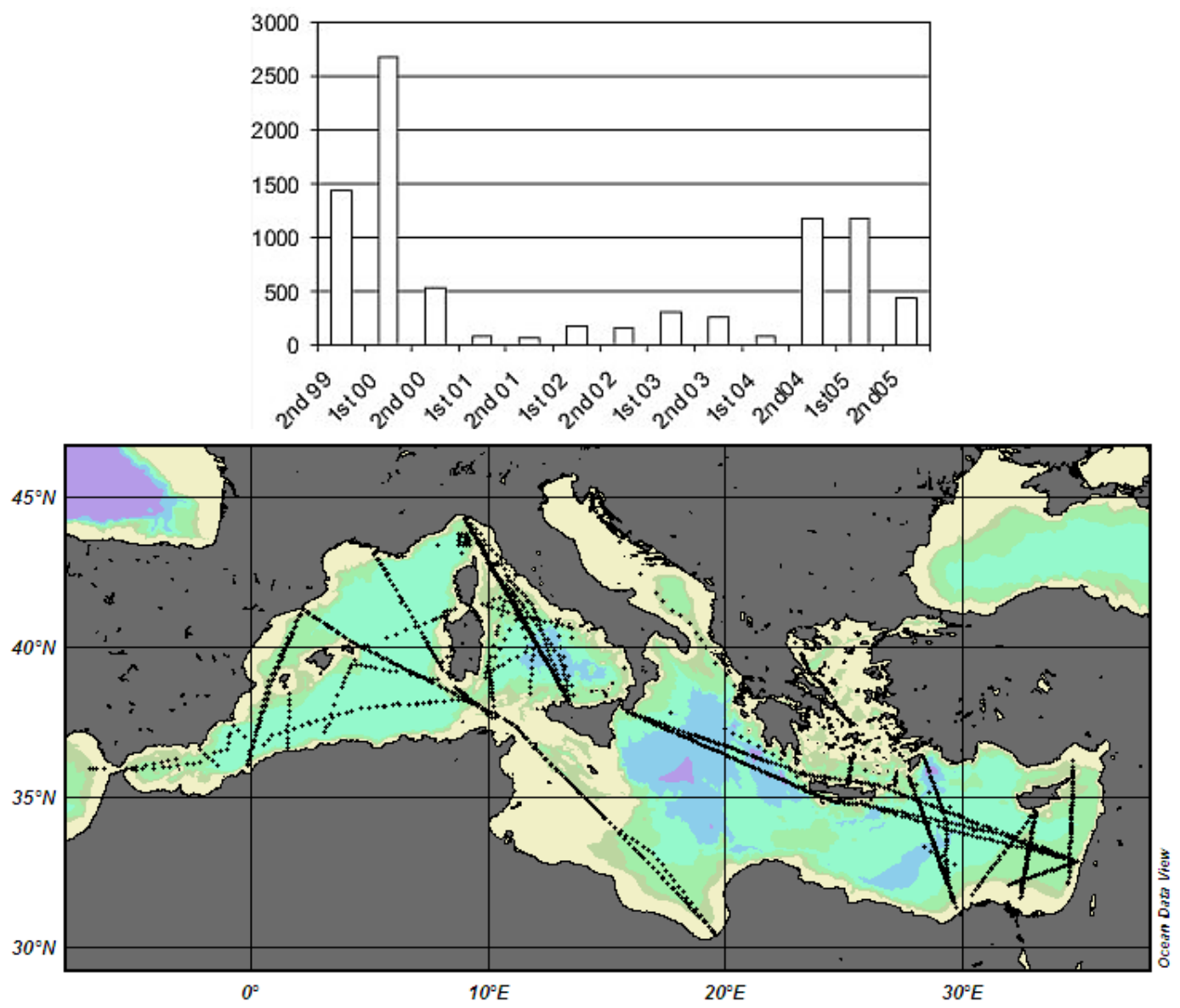

Fig. 2. (a) Schematic presentation of data collected in the Mediterranean on behalf of MFS-VOS from September 1999 to June 2005 . The amount of data is presented in semesters. On top of the figure is reported the specific program that sustained the data collection. MFS-PP was a EC funded project (1998-2001), ADRICOSM was a program financially supported by the Italian Ministry of Environment and Territory. (b) Sampling during the Mediterranean Forecasting System - Toward Environmental Prediction.

the Mediterranean circulation have emerged, as a result of particular observations or model realizations (Ovchinnikov et al., 1976; Özsoy et al., 1989, 1991, 1993; Robinson et al., 1992; Pinardi et al., 2004; Hamad et al., 2004; Millot and Taupier-Letage, 2005a; Hamad et al., 2005). It is indeed confirmed by the recent data-driven MFS-TEP forecasts (see monthly bulletins at http://www.bo.ingv.it/mfstep/WP8/ monthly.htm), that different forms of the proposed circulations can be observed at different times.

Transect Limassol-Port Said, Limassol-Alexandria (managed by the Oceanographic Centre, University of Cyprus, Fig. 3). During MFS-PP this SE Levantine transect was from Limassol (Cyprus) to Port Said (Egypt). In MFS-TEP, from May 2004 to October 2005, the destination was the same, except for/in December 2004 and January 2005, when the end port was Alexandria rewrite. The XBT data collection was extended until October 2005. In May 2004, the transect intersected the centre of the Cyprus warm core eddy within
Shikmona Gyre anti-cyclonic system. In September and October 2004, February, April and May 2005, the transects intersected the western periphery of the Cyprus eddy due to its eastward drift (as indicated by a depression of the isotherms; Zodiatis et al., 2005a). In December 2004 and January 2005 the transects did not cross the eddy, and homogeneous temperatures as low as $18.5^{\circ} \mathrm{C}$ were found down to about 100 $\mathrm{m}$.

Transects Mersin-Ashdod and Alexandria-Rhodes (managed by the Institute of Marine Science, Figs. 4a and b). XBT data were collected during the TOP period along a north-south transect east of Cyprus from Mersin to Ashdod, as well as along a transect from Alexandria to Rhodes, the latter one crossing the Rhodes Gyre, a permanent feature of the Levantine basin. In October 2004, various areas of deepening thermocline depth corresponding to anti-cyclonic centres were present (Fig. 4a), notably the coherent Lattakia eddy, east of Cyprus and also those in the southeast corner 

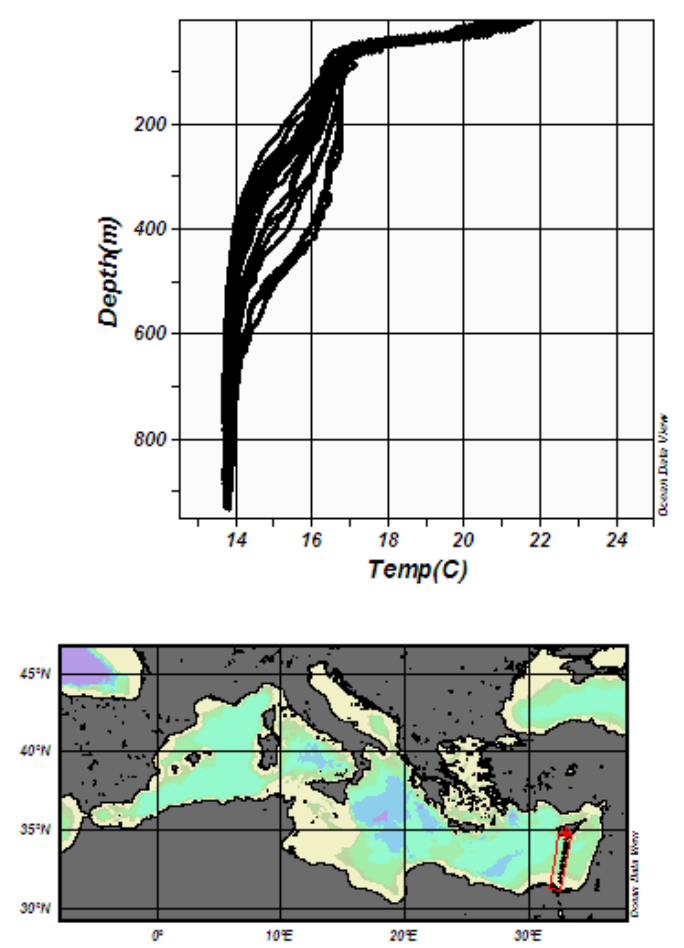

$\operatorname{Temp}(C)$

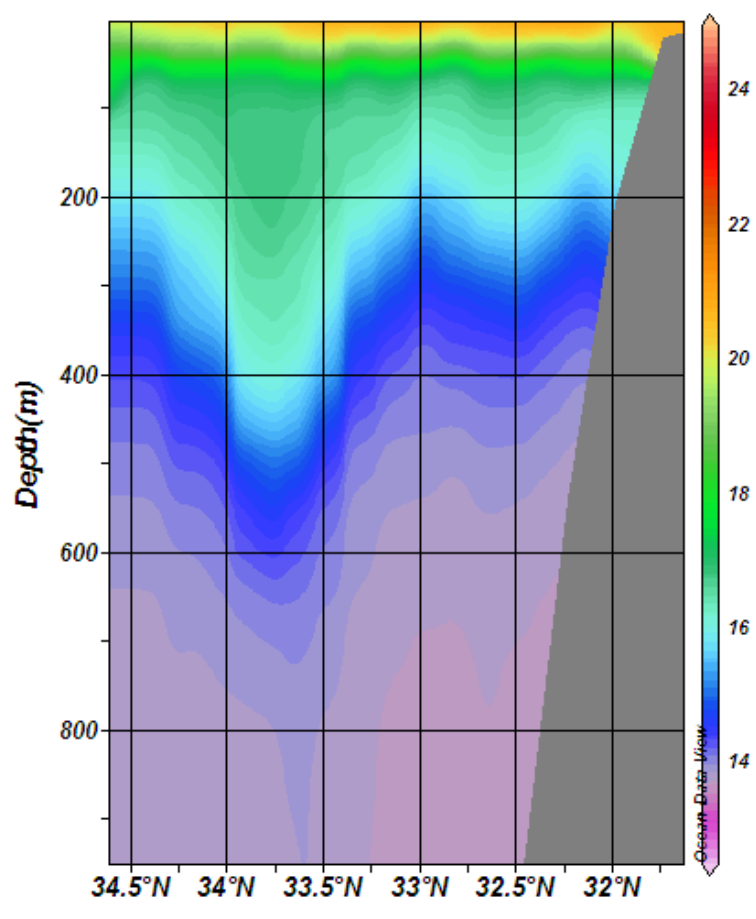

Fig. 3. Temperature section Limassol-Alexandria in May 2005. Similar behaviour of the isolines were obtained in most of the measurements along this transect.

of the basin well identified from satellite images. Significant thermal stratification was detected along the transects with the thermocline depth varying from about $100 \mathrm{~m}$ in the Egyptian area to $50 \mathrm{~m}$ inside the Rhodes Gyre. In December 2004 the thermocline depth was deeper, as a consequence of the atmospheric effects. The vertical homogeneity of the water mass in the centre of the Rhodes gyre was greater in the upper $300 \mathrm{~m}$ in February 2005 (Fig. 4b). The uniform temperatures could be the result of convection leading to dense water formation at the centre of the Rhodes Gyre, often extending to greater depths in the colder years as documented by Sur et al. (1992), Lascaratos and Nittis (1998) and MalanotteRizzoli et al. (2003).

Transect Heraklion-Thessaloniki (managed by Hellenic Centre for Marine Research, Fig. 5). This was another new transect introduced in MFS-TEP, with the aim to monitor an important area where dense water could be formed. The data show always three different waters in the Sporades, central Aegean and Cretan sub-basins (Fig. 5). In the Cretan subbasin the isotherms were always presenting a depression in the $100-500 \mathrm{~m}$ layer, except in winter (e.g. January 2005) when all transects were presenting a vertical homogeneity. The data collected in the northern part of the section did not present particular features.

Transect Haifa-Messina (managed by Institute of Oceanographic and Limnological Research, Fig. 6). The tran- sect from Haifa to Messina has shown the main features of the eastern basin, such as the Pelops, Ierapetra (south-east of Crete) and Cyprus-Shikmona anti-cyclones/anticyclones. In October-November and December 2004 the transects crossed the Iera-Petra eddy, presenting thermal depression down to $300 \mathrm{~m}$. The Rhodes Gyre was well evident as well as the Cyprus eddy. West of Crete, the transect intersected the Pelops eddy. In the Ionian the isotherms were presenting a slight surfacing of the thermocline, typical of cyclonic circulation. In January 2005, the eddies and gyres were much more evident. In particular, the Rhodes Gyre was presenting a higher vertical homogeneity, the Cyprus eddy was well developed, as well as the Iera-Petra eddy.

Transect Genova-Palermo (managed by Istituto Scienze Marine-Sezione La Spezia, Fig. 7). This transect started on May 2004 and is still continuing. Data in the Tyrrhenian show the well known Bonifacio Gyre, influenced by the westerly winds (Marullo et al., 1994). In the southern part of the Tyrrhenian, the data have shown a significant variability of the circulation. Sometimes the isotherms were indicating the presence of a cyclonic circulation (e.g. September and December 2004, February 2005), in other periods there were indications of a higher spatial variability with cyclonic and anti-cyclonic features. The data in the Ligurian are always indicating a cyclonic circulation whose intensity is varying seasonally. 

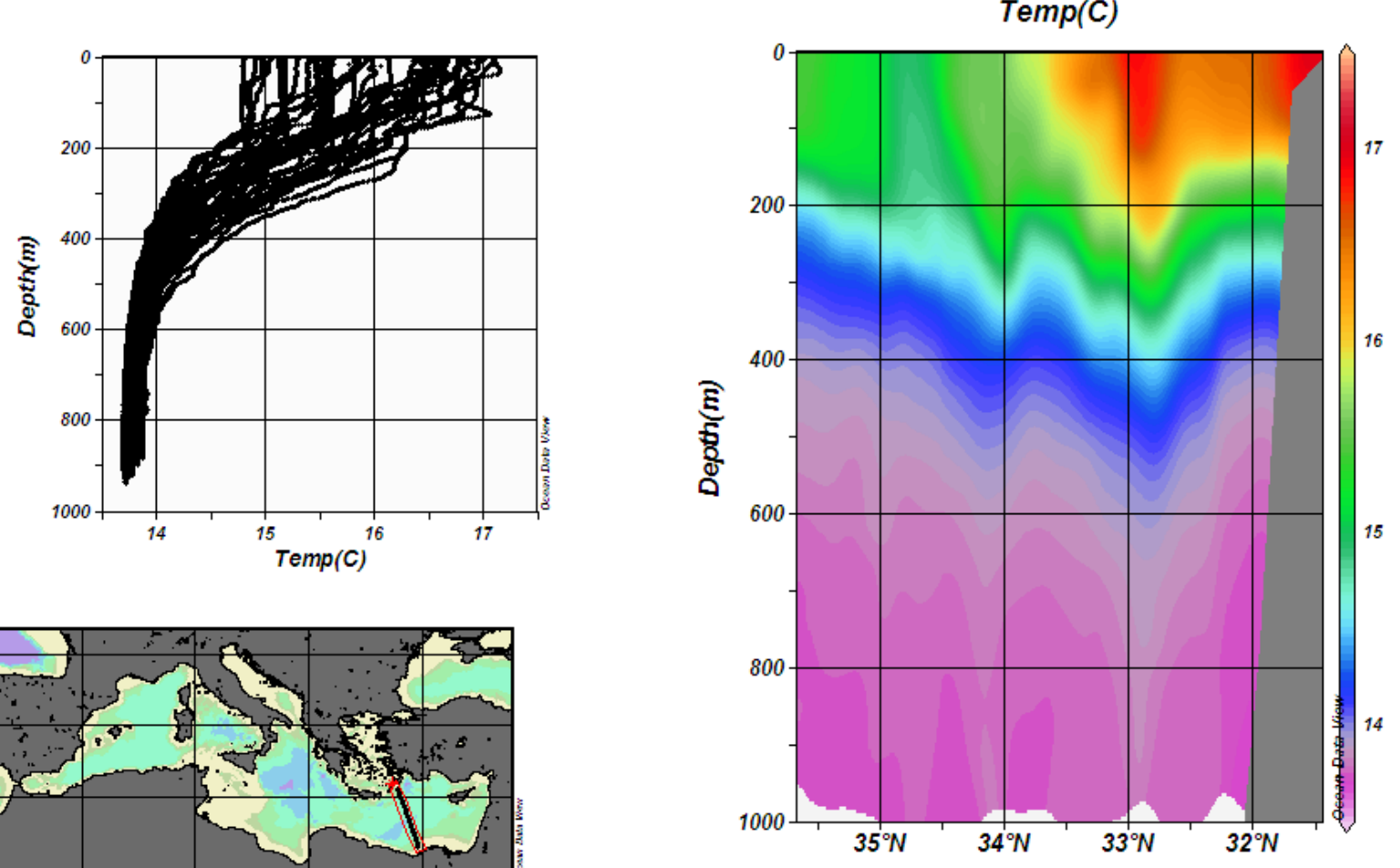

Fig. 4. Vertical section Alexandria-Rhodes in February 2005. A vertical homogeneous temperature was detected in the Rhodes gyre from surface to about $300 \mathrm{~m}$ depth.

Transect Marseille-Tunis (managed by Laboratoire d'Océanologie et de Biogéochimie - Antenne de Toulon, Fig. 8). One important feature is the zone of dense water formation in the Provençal (off the Gulf of Lions near $42^{\circ} \mathrm{N}$ ) where temperatures in February 2005 were homogeneous $\left(13.1-13.2^{\circ} \mathrm{C}\right)$ down to $1000 \mathrm{~m}$ (at least). Note that lower temperatures were found in the 100-200-m surface layer mainly more to the south (near $\sim 41^{\circ} \mathrm{N}$ ); because waters there have relatively low salinities, they are less dense than near $42^{\circ} \mathrm{N}$ and does not mix with the warmer and more saline intermediate waters. Still in the surface layer, note also the relatively large values close to the Tunisian slope (associated with the continuation of the Algerian Current) and the relatively low ones close to the French slope (associated with the Northern Current) which both sign the basin-wide along-slope gyre (see Millot and Taupier-Letage, 2005a). At intermediate depths, the relative maxima found along-slope (at $\sim 300 \mathrm{~m}$ south and west off Sardinia and $\sim 500 \mathrm{~m}$ off France) clearly trace the along-slope circuit of LIW as specified by Millot (1987; see consistency with other transects too).

Transect Barcelona-Mersa el Brega (managed by Centre de Estudis Advançat de Blanes, Fig. 9). This transect substituted the original Barcelona-Arzew transect in November 2004, end of January and February 2005. The Algerian was presenting a high spatial variability, as depicted in the circulation scheme by Millot (1999). The importance of this transect, lies in the fact that data have been collected in the southern Ionian for the first time after many years. There are some important patterns that are worthy of attention, such as the entrance of relatively warm water at about $140 \mathrm{~m}$ from the Ionian, visible from $35^{\circ} \mathrm{N}$ to North of Tunisia coast. Also some eddies were observed in the Gulf of Syrte, as first depicted by Hamad et al. (2004) and detailed in Hamad et al. (2006).

Transect Barcelona-Arzew (managed by Centre de Etudis Advancat de Blanes, Fig. 10). This was done in alternative to the previous transect and show the northern part of the along slope Northern Current and the instabilities in the eastern Alboran Sea). A surfacing of the thermocline was observed in September, October and November 2004 between the Balearic Islands and Algeria, but no other significant features were observed. At intermediate depths (200-400 m), the relatively large temperatures associated with LIW are found along the Spanish continental slope. In the Algerian sub-basin, largest temperatures are found offshore (near $37^{\circ} \mathrm{N}$ ), and could be associated to LIW transported slope by Algerian eddies (Millot, 1987; Millot and Taupier-Letage, 2005b). 

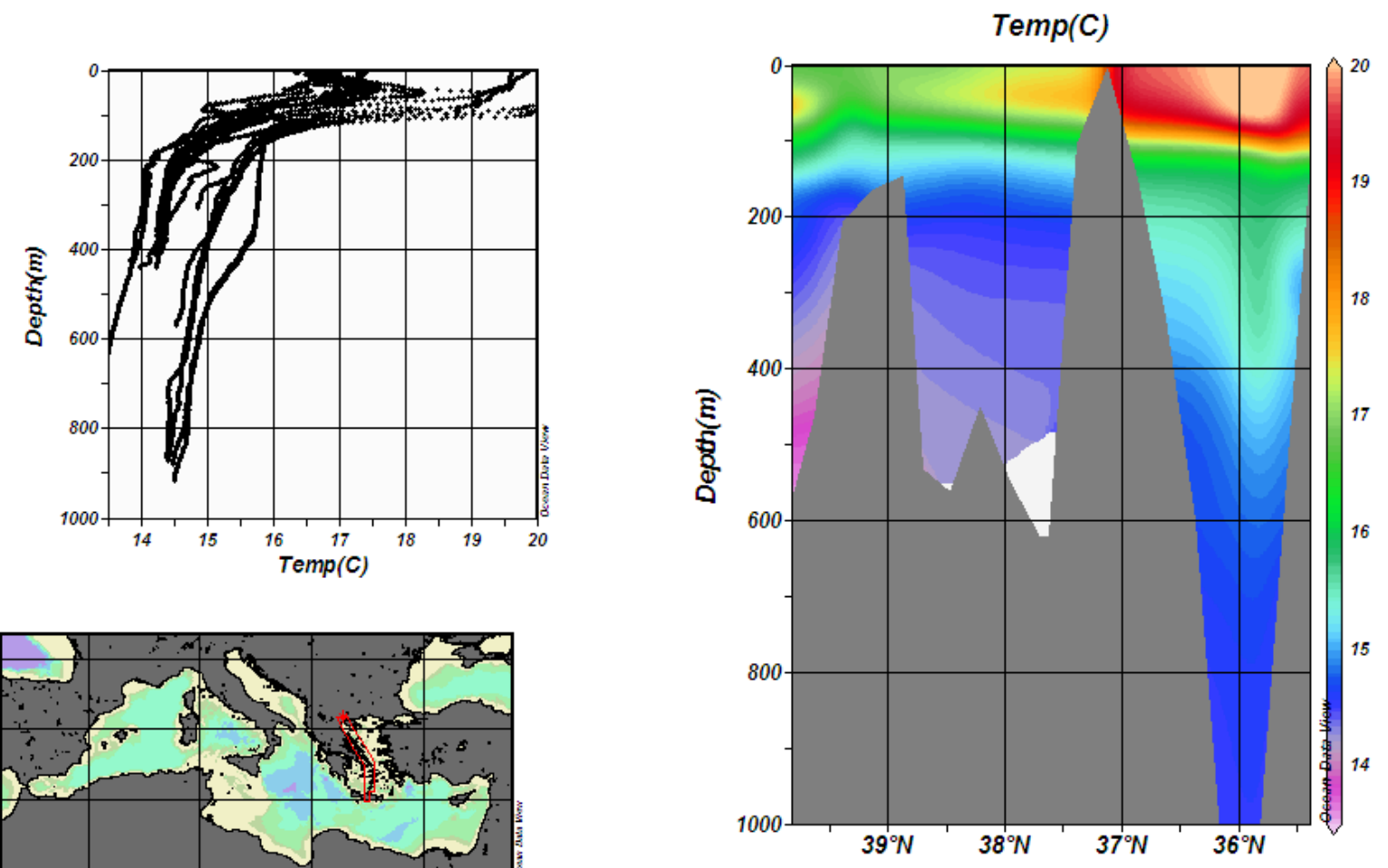

Fig. 5. Vertical section Heraklion-Thessaloniki in December 2004. The three different water masses existing in the Aegean Sea are clearly visible in the figure.
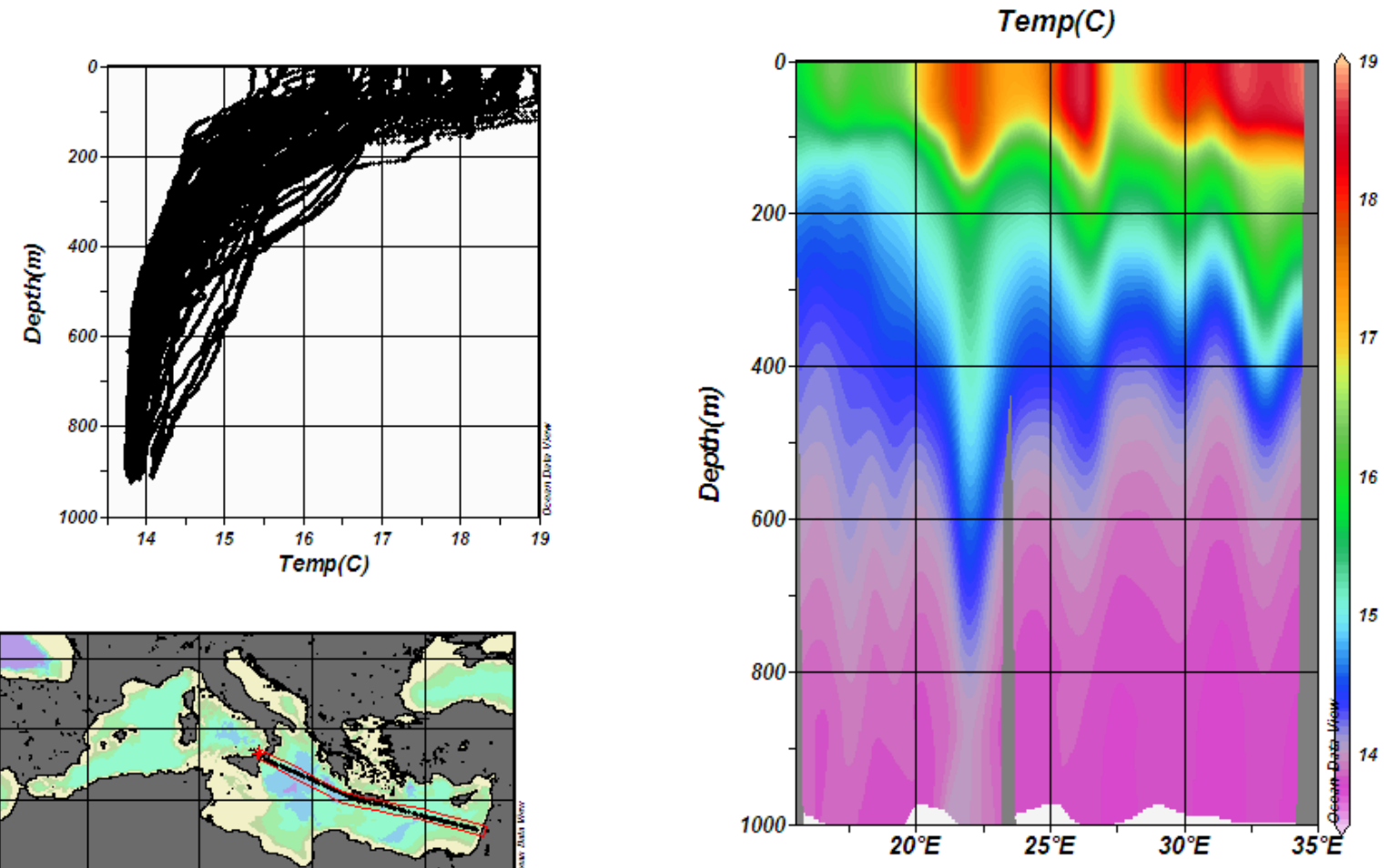

Fig. 6. Vertical section Haifa-Messina in January 2005. The figure show the main eddies in the eastern basin. 

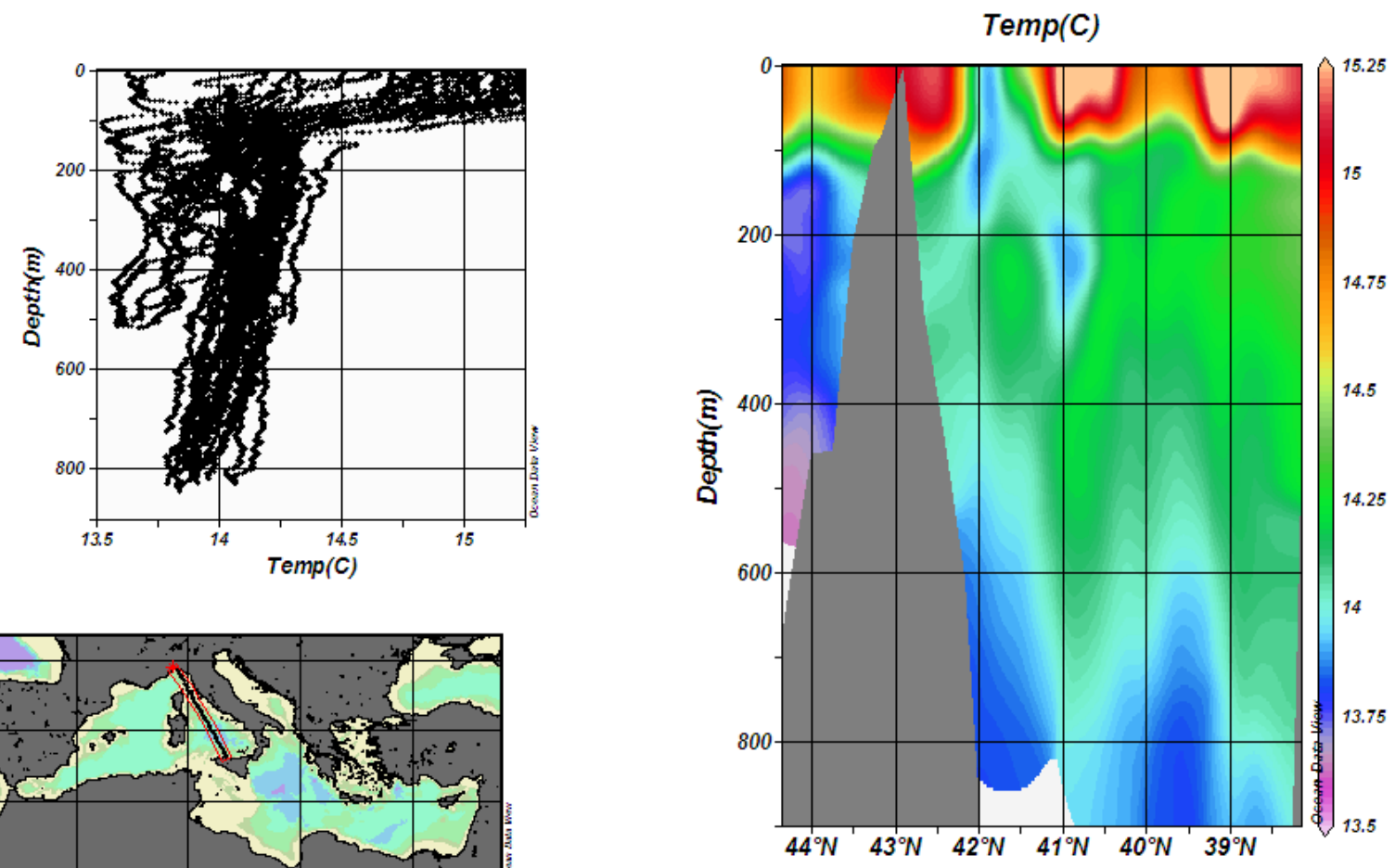

Fig. 7. Vertical section Genova-Palermo in January 2005.
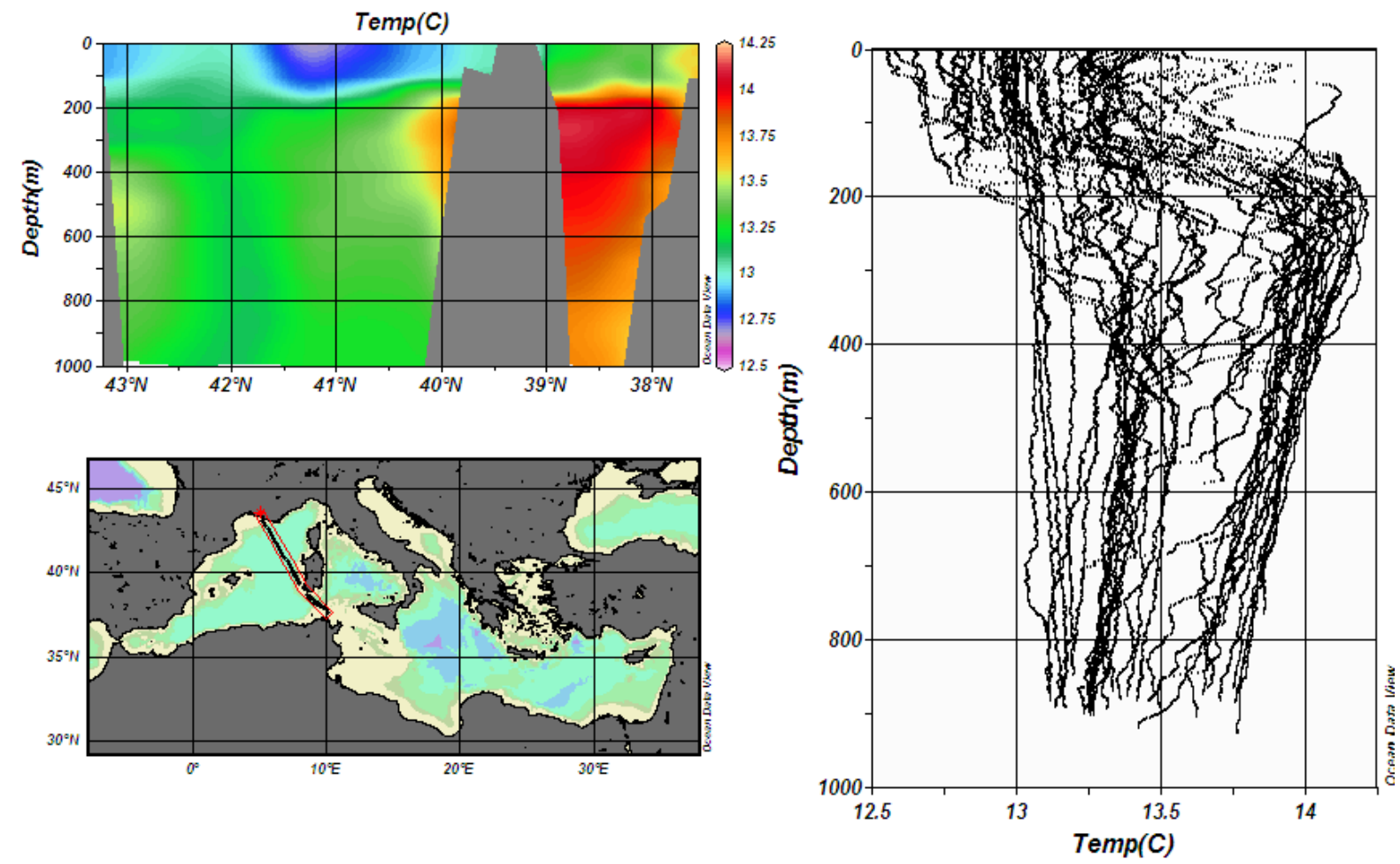

Fig. 8. Vertical section Marseille-Tunis in February 2005, when vertically homogeneous temperature profiles were collected. 

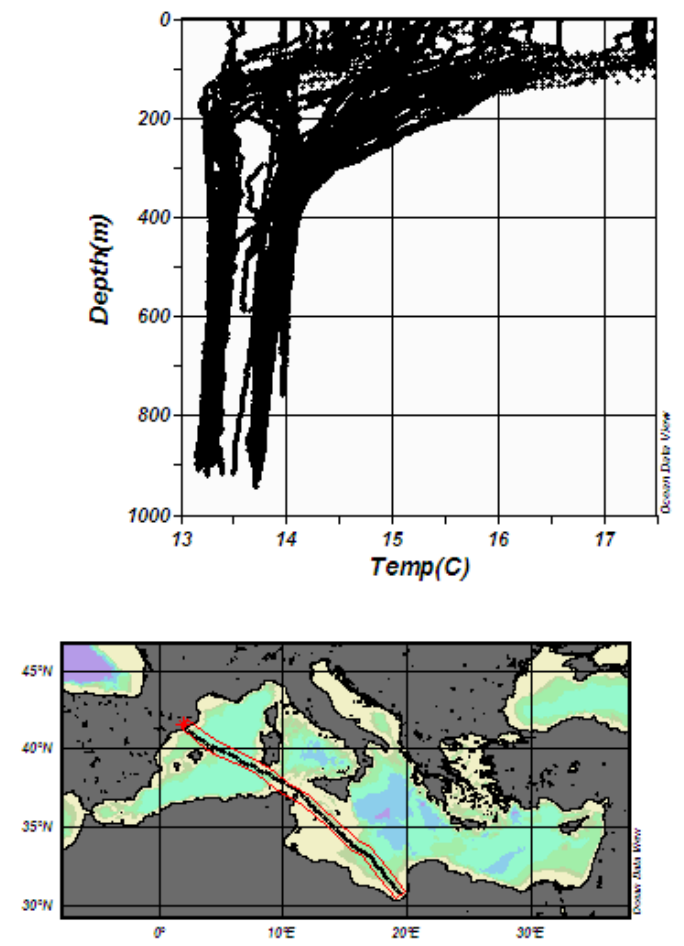

Fig. 9. Vertical section Barcelona-Mersa el Brega in January 2005.
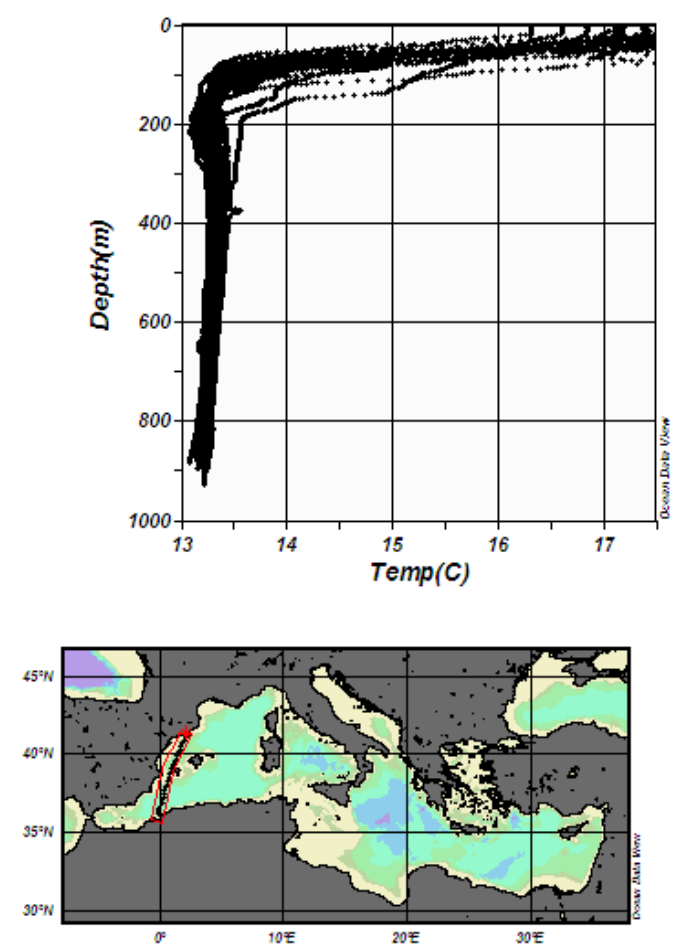

Fig. 10. Vertical section Barcelona-Arzew in November 2004.
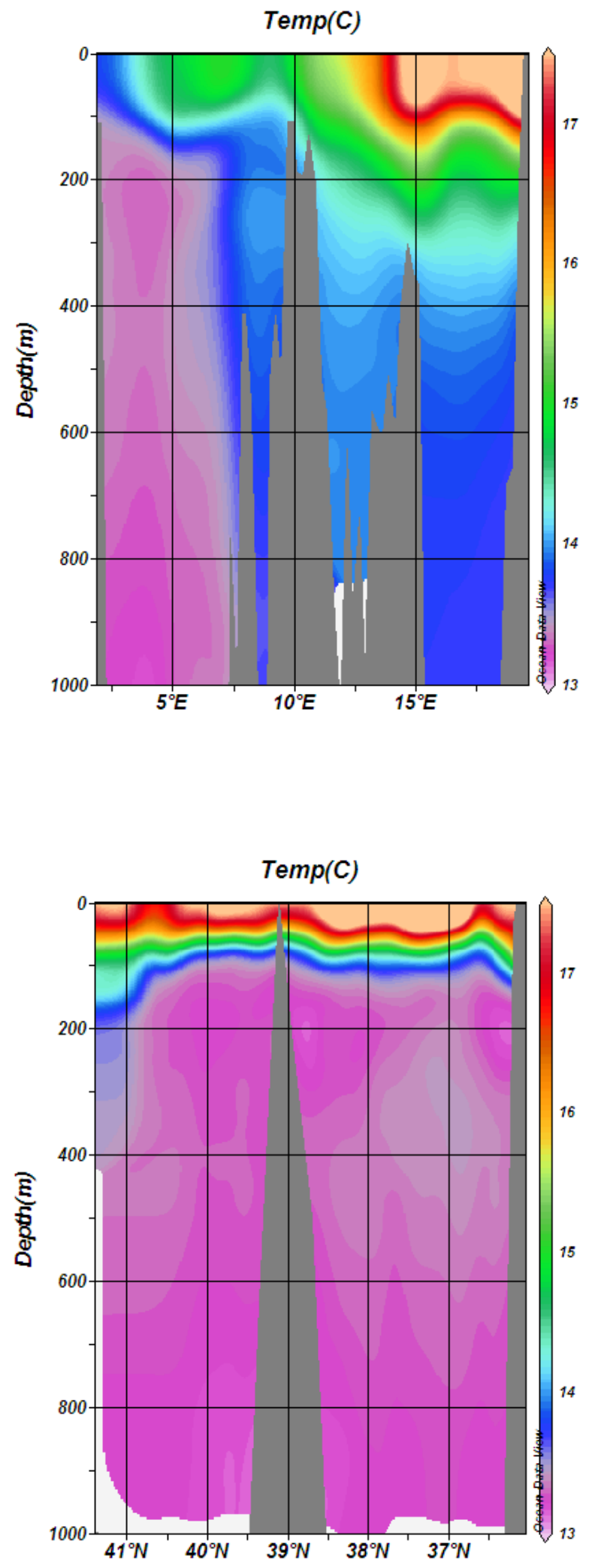


\section{The MFS-VOS service}

The main objective of MFS-VOS was, initially, the provision of data to the Mediterranean Forecasting System. Year after year, the scope was enlarged in order to reach the need of a wider community of users: research, private companies and the public.

The data arriving in the MFS-VOS thematic centre are soon displayed in the main web page. The user can select the data on a geographical, temporal and parametric base, and she/he can plot the profiles and look at the data and metadata before downloading.

A statistic of the access to the web pages show that at least one user is using the service every day. Most of them are using only the view service, and probably are those users normally called "general public", who want to be informed on the status of the Mediterranean. Some others are downloading data. These users are belonging to private, academic or public sectors and are probably part of the so called "intermediate users", i.e. they use the data collected in MFS-VOS to produce new information or services.

The MFS-VOS system is assuring the quality of the data, the timeliness, a view service and an easy access, but need to establish collaboration with the users, in order to better finalise the data collection.

\section{Discussion and conclusions}

The ships of opportunity program started in the Mediterranean in September 1999, and since that time has continued to provide XBT-temperature profiles. The objective of the program is the provision of quality data to the Mediterranean Forecasting System and to other external users. For this reason, some quality control procedures were implemented, such as: quality assurance of fieldwork and quality control of data.

In order to fulfil the scope, many implementations have been introduced in the data collection, transmission and management. The implementations have been the result of a continuous process of improvement of the observing system.

- In order to assure a high quality to data, selected probes from different batches have been calibrated at the NURC centre in La Spezia, at different reference temperatures. The precision of the temperature measurements as deduced from the static calibration is of 0.04$0.08^{\circ} \mathrm{C}$. This result (temperatures measured by XBTs warmer than real of about $0.05-0.10^{\circ} \mathrm{C}$ ) is also confirmed by a comparison between measurements done by ARGO floats near XBT launches. The difference in time and in position has been selected within few days and few miles (see Emelianov et al., 2006).

- The XBT probes are used in an 'extensive' mode, i.e. the LM Sippican software is set in a way that the data can be collected below the nominal depth (Reseghetti et al., 2007). With Deep Blue probes it is thus possible to measures down to about $900 \mathrm{~m}$. This small implementation allows inferring more information on the deeper stratification in the Mediterranean.

- Full resolution data are transmitted by using GSM or satellite telecom systems (Globalstar). This avoid the loose of information in the temperature profiles (Manzella et al., 2003) and in the metadata.

- Data are transmitted as an e-mail to the MFS-VOS Thematic Centre, where they are processed and included in a ftp site, where they can be accessed by any user.

The protocols and methodologies for data collection, transmission and quality control have been definitively tested in MFS-TEP, checking that the monitoring system is adequate to specify the main circulation features of the Mediterranean and their variability. Meanwhile, some basic services have been developed, in order to allow users to have general information on data and thermal variability in the Mediterranean.

The system is now mature to move from a pre-operational project to a full operational phase. This will be done in two ways: selecting the most significant transects, and improving the technology for an improved two-way automated data collection and transmission system.

The passage from the pre-operational to the operational phase must include also the implementation of services for users. MFS-VOS is providing data to forecasting system and, through the acquisition of long time series, to climatic studies. However, this is not exhausting the scope of MFS-VOS. Data have a value "per se", and many products can be derived from them, such as ("inter alia"): maps on the thermal state of the sea, differences with respect to climatology, implemented climatologies.

The other value of MFS-VOS data is in its capability to monitor changes at seasonal and interannual scales. In October 2004 it was detected the cyclonic Alboran Gyre (that is normally an anti-cyclonic circuit) closer to Gibraltar followed by an anti-cyclonic gyre to the east. This situation is not usual, since the first anti-cyclonic gyre is normally followed by a second one, but the data interpretation is also in agreement with MFS-TEP analysis (MFSTEP Bulletin, October 2004), although some other interpretations could be possible, i.e. a cyclone between two anti-cyclones.

In general, the instabilities associated with the Algerian current are normally interesting the upper 100-200 m (Millot and Taupier-Letage, 2005). However, a deep anti-cyclonic eddy was detected in October 2004 at about $6^{\circ}$ E. CTD data collected in the same area by Urania show that the eddy is deeper than $1000 \mathrm{~m}$ (consistent with previous data and e.g. Millot and Taupier-Letage, 2005b). Instabilities associated with the AW were influencing, as expected, also the circulation in the Sardinia Channels. The cyclonic circulation in the 
Gulf of Lion and in the Ligurian Sea was detected as usual, as well as the Gyre of Bonifacio. In the eastern basin the main features are represented by the anti-cyclonic circulation in the Ionian, the Pelops, Iera-Petra and Cyprus eddies. It was also evident the cyclonic Rhodes Gyre and the anti-cyclonic circulation in the Mersa-Matruh area.

The XBT transects in the south-east Levantine show the Cyprus eddy to drift for about $20 \mathrm{~nm}$ (from September 2004 to May 2005, and then westward (from June to October 2005) back to its previous position, as it was observed in May 2004.

The collection of data in areas of dense water formation during winter extreme events are among the success of the monitoring system,

Acknowledgements. MFS-VOS has been supported by the EC project MFS-TEP under contract EVK3-CT-2002-00075, and the UNESCO - Italian Ministry of Foreign Affairs - Italian Ministry of Territory and Environment project ADRICOSM EXT. The authors are indebted with owners, captains and crews of the following ships: Britain Star (Zim Company), Annabella, Methane Polar and Methane Arctic (CS/Osprey), Mont Ventoux (Delom), Excellent, La Superba and La Suprema (Grandi Navi Veloci), Mehmet Kalkavan (Turkon), Princesa Marissa and Serenade (Louis Company), Celtic Ambassador (Zim Company) and EAS (EDT Offshore), Daedalos (Daedalos). Authors acknowledge G. Muzio from Grandi Navi Veloci, E. Lazzoni and F. Dell'Amico from CNR-ISMAR-SP, M. Morgigni from ENEA, M. Demirel from the IMS-METU, and M. Ioannou and S. Savva from the Cyprus Oceanography Centre, B. Kazenelson and D. Ramot from IOLR, for the assistance and efforts during the data collection. The free software Ocean Data View by R. Schlitzer is extensively used in MFS-VOS. We acknowledge an unknown referee, whose comments were useful for the improvement of this paper.

Edited by: N. Pinardi

\section{References}

AODC: Guide to MK12 - XBT System (Including Launching, returns and faults), Australian Oceanographic Data Centre (AODC), METOC Services, 1-63, 1999.

AODC: Expendable Bathythermographs (XBT) delayed mode. Quality control manual. Australian Oceanographic Data Centre (AODC), Data Management Group, Technical Manual 1/2001, $1-24,2001$.

Brenner, S.: Structure and evolution of warm core eddies in the Eastern Mediterranean Levantine Basin, J. Geophys. Res., 94, 12 593-12 602, 1989.

Cook, S. and Sy, A.: Best guide and principles manual for the Ships Of Opportunity Program (SOOP) and EXpendable Bathythermograph (XBT) operations. Prepared for the IOC-WMO-3rd Session of the JCOMM Ship of Opportunity Implementation Panel (SOOPIP-III), 28-31 March 2000, La Jolla, California, USA, 126, 2001.

Demirov, E., Pinardi, N., Fratianni, C., Tonani, M., Giacomelli, L., and DeMey, P.: Assimilation scheme of the Mediterranean Forecasting System: operational implementation, Ann. Geophys., 21,
189-204, 2003,

http://www.ann-geophys.net/21/189/2003/.

Emelianov, M., Font, J., Turiel, A., Millot, C., Solé, J., Poulain, P.-M., Julià, A., and Vitrià, M.-R.: Transformation of Levantine Intermediate Water tracked by MEDARGO floats in the Western Mediterranean, Ocean Sci., 2, 281-290, 2006,

http://www.ocean-sci.net/2/281/2006/.

Fusco, G., Manzella, G. M. R., Cruzado, A., Gacic, M., Gasparini, G. P., Kovacevic, V., Millot, C., Tziavos, C., Velasquez, Z., Walne, A., Zervakis, V., and Zodiatis, G.: Variability of mesoscale features in the Mediterranean Sea from XBT data analysis, Ann. Geophys., 21, 21-32, 2003,

http://www.ann-geophys.net/21/21/2003/.

Gascard, J. C.: Mediterranean deep water formation, baroclinic instability and oceanic eddies, Oceanologica Acta, 1, 3, 315-330, 1978.

Groom, S., Herut, B., Brenner, S., Zodiatis, G., Psarra, S., Kress, N., Krom, M. D., Law, C. S., and Drakopoulos, P.: Satellite derived spatial and temporal biological variability in the Cyprus Eddy, Deep Sea Res. II, 52, 2990-3010, 2005.

Hamad, N., Millot, C., and Taupier-Letage, I.: The surface circulation in the eastern basin of the Mediterranean Sea: new elements, Proceeding of the Ankara Conference, October 2002, 2-9, 2004.

Hamad, N., Millot, C., and Taupier-Letage, I.: A new hypothesis about the surface circulation in the eastern basin of the Mediterranean Sea, Progress in Oceanography, 66, 287-298, 2005.

Hamad, N., Millot, C., and Taupier-Letage, I.: The surface circulation in the eastern basin of the Mediterranean Sea, Scientia Marina, 70(3), 505-517, 2006.

Hecht, A., Robinson, A., and Pinardi, N.: Currents, water masses, eddies and jets in the Mediterranean Levantine basin, J. Phys. Oceanog., 8, 1320-1353, 1988.

Hecht, A. and Gertman, I.: Physical features of the eastern Mediterranean resulting from the integration of POEM data with Russian Mediterranean cruises, Deep-Sea Res. I, 48, 1847-1876, 2001.

Klein B., Roether W., Manca B.B., Bregant D., Beitzel V., Kovacevic V., and Lucchetta, A.: The large deep water transient in the eastern Mediterranean, Deep Sea Res. I, 46, 371-414, 1999.

Klein, B., Roether, W., Civitarese, G., Gacic, M., Manca, B. B., and Ribera d'Alcalà, M.: Is the Adriatic returning to dominate the production of Eastern Mediterranean Deep Water?, Geophys. Res. Lett., 27, 3377-3380, 2000.

Lascaratos, A. and Nittis, K.: A high resolution 3-D numerical study of intermediate water formation in the Levantine Sea, J. Geophys. Res., 103, 18 497-18 511, 1998.

Leaman, K. D. and Schott, F.: Hydrographic structures of the convection regime in the Gulf of Lions, winter 1987, Journal Phys. Oceanogr., 21, 575-598, 1991.

Malanotte Rizzoli, P., Manca, B. B., Ribera d'Alcalà, M., Theocaris, A., Brenner, S., Budillon, G., and Özsoy, E.: The eastern Mediterranean in the $80 \mathrm{~s}$ and in the $90 \mathrm{~s}$ : the big transition in the intermediate and deep circulation, Dynamics of Atmospheres and Oceans, 29, 365-395, 1999.

Malanotte-Rizzoli, P., Manca, B. B., Marullo, S., and Özsoy, E.: The Levantine Intermediate Water Experiment (LIWEX) Group: Levantine basin - A laboratory for multiple water mass formation processes, J. Geophys. Res.-Oceans, 108(C9), 8101, doi:10.1029/2002JC001643, 2003.

Manzella, G. M. R., Cardin, V., Cruzado, A., Fusco, G., Gacic, 
M., Galli, C., Gasparini, G. P., Gervais, T., Kovacevich, V., Millot, C., Petit de la Villeon, L., Spaggiari, G., Tonani, M., Tziavos, C., Velasquez, Z., Walne, A., Zervakis, V., and Zodiatis G.: Project improves monitoring of circulation variability in the Mediterranean Sea, EOS, 497-504, 2001.

Manzella, G. M. R., Scoccimarro, E., Pinardi, N., and Tonani, M.: Improved near real time data management procedures for the Mediterranean ocean Forecasting System - Voluntary Observing Ship program, Ann. Geophys., 21, 21-32, 2003, http://www.ann-geophys.net/21/21/2003/.

Marullo, S., Santoleri, R., and Bignami, F.: The surface characteristics of the Tyrrhenian Sea: historical satellite data analysis, in: Seasonal and Interannual variability of the Western Mediterranean Sea, AGU Coastal and estuarine studies 46, edited by: La Violette, P. E., 135-154, 1995.

MedAtlas Group: Specification for Mediterranean banking and regional quality controls. IFREMER, Direction Scientific, SismerBrest, SISMER/IS/94-014, pp. 29, 1994.

Millot, C.: The circulation of the Levantine Intermediate Water in the Algerian Basin, J. Geophys. Res., 92(C8), 8265-8276, 1987.

Millot, C.: Circulation in the Western Mediterranean Sea, J. Mar. Syst., 20, 1-4, 423-442, 1999.

Millot, C. and Taupier-Letage, I.: Circulation in the Mediterranean Sea. The handbook of environmental chemistry, Vol. K (The Natural Environment and the Biological Cycles), Springer-Verlag Editor, 29-66, 2005a.

Millot, C. and Taupier-Letage, I.: Additional evidence of LIW entrainment across the Algerian Basin by mesoscale eddies and not by permanent westward-flowing vein, Progress in Oceanography, 231-250, 2005b.

Ovchinnikov, I. M., Plakhin, A., Moskalenko, L. V., Neglyad, K. V., Osadchii, A. S., Fedoseev, A. F., Krivosheya, V. G., and Votive, K. V.: Gidrologiia Sredizemnogo Moria. Gidrometeoizdat, Leningrad, 375 pp. (in Russian), 1976.

Özsoy, E., Hecht, A., and Ünlüata, Ü.: Circulation and hydrology of the Levantine Basin. Results of POEM Coordinated Experiments 1985-1986, Progress in Oceanography, 22, 125-170, 1989.

Özsoy, E., Hecht, A., Ünlüata, Ü., Brenner, S., Oguz, T., Bishop, J., Latif, M. A., and Rosentroub, Z.: A review of the Levantine Basin circulation and its variability during 1985-88, Dyn. Atmos. Oceans, 15, 421-456, 1991.

Özsoy, E., Hecht, A., Ünlüata, Ü., Brenner, S., Sur, H.Ý., Bishop, J., Latif, M. A., Rozentraub, Z., and Oguz, T.: A synthesis of the Levantine Basin circulation and hydrography, 1985-1990, DeepSea Res., 40, 1075-1119, 1993.
Pinardi, N., Allen, I., Demirov, E., DeMey, P., Korres, G., Lascaratos, A., LeTraon, P.-Y., Maillard, C., Manzella, G., and Tziavos, C.: The Mediterranean ocean Forecasting System: first phase of implementation (1998-2001), Ann. Geophys., 21, 320, 2003, http://www.ann-geophys.net/21/3/2003/.

POEM Group: General Circulation of the Eastern Mediterranean Sea, Earth Sci. Rev., 32, 285-309, 1992.

Raicich, F. and Rampazzo, A.: Observing system simulation experiments for the assessment of temperature sampling strategies in the Mediterranean Sea, Ann. Geophys., 21, 151-166, 2003, http://www.ann-geophys.net/21/151/2003/.

Reseghetti, F., Borghini, M., and Manzella, G. M. R.: Factors affecting the quality of XBT data - results of analyses on profiles from the Western Mediterranean Sea, Ocean Sci., 3, 59-75, 2007, http://www.ocean-sci.net/3/59/2007/.

Roether, W., Manca, B. B., Klein, B., Bregant, D., Georgopoulos, D., Beitzel, V., Kovacevich, V., and Luchetta, A.: Recent changes in the eastern Mediterranean deep water, Science, 271, 333-335, 1996.

Smith, N. R., Harrison, D. E., Bailey, R., Delcroix, T., Hanawa, K., Keely, B., Meyers, G., Molinari, B., and Roemmich, D.: The role of XBT sampling in the ocean thermal network, OCEANOBS St. Raphael 18-22 October, 1999.

Sur, H.Ý., Özsoy, E., and Ünlüata, Ü.: Simultaneous deep and intermediate depth convection in the northern Levantine Sea, winter, Oceanol. Acta, 16, 33-43, 1992.

Zodiatis, G., Manca, B., and Balopoulos, E.: Synoptic, seasonal and interannual variability of the warm core eddy south of Cyprus, SE Levantine basin, Rapp. Comm. Int. Mer Medit., 36, 89-90, 2001.

Zodiatis, G., Drakopoulos, P., Brenner, S., and Groom, S.: Variability of the Cyprus warm core Eddy during the CYCLOPS project, Deep Sea Res. II, 52, 2897-2910, 2005a.

Zodiatis, G., Drakopoulos, P., Gertman, I., Brenner, S., and Hayes, D.: The Atlantic Water Mesoscale Hydrodynamics in the Levantine Basin, 27th CIESM Monograph on Strategies for understanding mesoscale processes, pages 131, Villefranche-sur-mer, 25-28 March 2005. 